\title{
İklim Değişikliğine Direnç: Yerküre için Karbon Detoksu (Karbon Arınımı)
}

\author{
Mithat EKICi ${ }^{1 *}$
}

\begin{abstract}
Öz
İklim ve iklim değişiklikleri insanlığın varlığından beri yaşamı çok fazla etkileyen önemli bir unsur olmuştur. Dünya var olduğundan beri doğal yollar ile oluşmuş birçok iklim değişikliği dönemi yaşanmıştır. Günümüz bilim adamlarının okyanus tabanından, kutup buzullarından, dağ buzullarından aldıkları karotlar sayesinde bu dönemler anlaşılmıştır. Son zamanlarda yaşanan küresel ısınma ve iklim değişikliğinin sebebi insan kaynaklı endüstriyel sera gazlarıdır. Bu konuda neredeyse tüm iklim bilimi çalışan bilim insanları hemfikirdir. Küresel ısınmaya bağlı iklim değişikliğinin sebebi olan insanoğlu, aynı zamanda, bu durumu düzeltecek ve sonlandıracak tek unsurdur. Bunun sağlanmasının yolu ise uluslar, hükümetler, topluluklar, aileler ve bireyler düzeyinde yapabileceklerin bilinmesi ve uygulanmasıdır. İnsanların farkındalığının artırılması iklim değişikliğine direnç en önemli sorunlarından biridir. Farkındalığa yardımcı olacak bir terimin geliştirilmesi iklim değişikliğine direnç için toplumlara yardımcı olacaktır. İklim değişikliği için Direnç: Karbon Detoksu kavramı iklim değişikliğine direnç için bireylerin kullanabileceği yeni bir kavramdır. Bu çalışmanın amacı, dikkat çekici ve uygulanabilir yöntemlerin tanıtımı sayesinde karbon detoksu (arınma) teriminin ve bu yaklaşımın hayatın bir parçası olmasının sağlanmasıdır. Karbon detoksunun uygulanabilmesi için bireylerin karbon ayak izinin hesaplanması ve sonuçta $\mathrm{CO}_{2}$ salımının azaltılmasının mümkün olmasıdır.
\end{abstract}

Anahtar Kelimeler: Iklim Değişikliği, Iklim Değişikliğine Direnç, Karbon Detoksu, Karbon Ayakizi,

\section{Resilience to the Climate Change: Carbon Detox for the Earth}

\begin{abstract}
\footnotetext{
${ }^{1}$ Meteoroloji Genel Müdürlüğü, Türkiye

* Illgili yazar / Corresponding author:mekici@mgm.gov.tr

Gönderim Tarihi / Submission Date: 28.01.2019

Kabul Tarihi / Acception Date: 17.06.2019
}

Climate and climate changes have been an important factor that has affected life a lot since the existence of humanity. Since the world has existed, there have been many periods of climate change occurring by natural means. These periods are understood by the drilling cores that today's scientists have taken from the ocean floor, the polar glaciers and the mountain glaciers. The recent global warming and climate change are caused by humaninduced industrial greenhouse gases. Almost all the scientists working on climate change 
agree that is the man-made climate change. The human being, which is the cause of climate change due to global warming, is also the only element that will correct and end this situation. The way to achieve this is to know and implement what can be done at the level of nations, governments, communities, families, and individuals. Increasing people's awareness is one of the most important problems for resistance to climate change. The concept of carbon detoxification that will help raise awareness will help communities to resist climate change. Resilience to Climate Change: The concept of Carbon Detox is a new concept that individuals can use for resistance to climate change. The aim of this study is to ensure that carbon detox (purification) and this approach are a part of life through the introduction of remarkable and applicable methods. It is possible to calculate the carbon footprint of individuals and consequently to reduce $\mathrm{CO}_{2}$ emissions in order to apply carbon detox.

Key Words: Climate Change, Resilience to the Climate Change, Carbon Detox, Carbon Footprint,

\section{GíRiş}

İklim, tüm canlıların ve özellikle de insanların hayatını var olduklarından beri en çok etkileyen unsurlardan birisi olmuştur. İnsanlık tarihi boyunca iklim yüzünden büyük ve küçük göç hareketleri yaşanmış, savaşlar çıkmıştır. Semavi dinlerin ortak Nuh Tufanı mitolojisi dahi iklim ile ilgilidir. İnsanlık iklime ayak uydurmak için icatlar, keşifler yapmıştır. Buna benzer olayların yaşandığı dönemlerde yaşanan iklim değişiklikleri doğal iklim değişiklikleridir. Paleohidroloji ve paleo-klimatoloji sayesinde iklim verilerinin türetilmesi yönündeki çalışmalar için çok eski geçmişe gidebilmemizi sağlayan kutuplardaki buz kütleleri, mercanlar, ağaç halkaları, okyanus ve göllerdeki sedimanlar gibi doğal kaynaklardan alınan karotlar sayesinde iklimsel ve hidrolojik olarak geçmişin değişiklikleri anlaşılabilmektedir (Şarlak 2015: 500). Bu paleo-iklimsel vekil veriler sayesinde dünyan var olduğundan beri birçok doğal iklim değişimi yaşadığı belgelenmiştir. Son birkaç yüzyıl içerisinde dahi bu değişeme ait örnekler mevcuttur. 17. ve 19. yüzyıllar arasında Avrupa'da mini buzul çağı yaşanmıştır (Mann 2002: 1). Çok büyük volkanik patlama yıllarını takiben 1-2 yıl daha devam eden yaz sıcaklığı ve yağış istatistiklerinde anlamlı azalmalar tespit edilmiştir. Volkanik patlamaları takiben ilk yaz sıcaklıklarında soğuma anomalileri hemen hemen tüm dünyada yaşanmaktadır (Man vd., 2014: 7406). Tüm bu yaşanan doğal iklim değişikliği örnekleri, son yıllarda yaşadığımız ve hızla karbon miktarını yükselterek sera gazı etkisini artırdığımız iklim değişikliğinden farklı sebeplerle oluşmuştur. Bilim çevrelerince son çalışmalar yaşanan iklim değişikliğinin sebebinin insan yapımı sera gazlarından kaynaklı bir değişim olduğunu ortaya koymaktadır. Yani bu durum az veya çok tüm insan kaynaklı ve dünyayı felakete sürükleyen bir durumdur. Az veya çok insanların sorumlu olduğu kabul edilirse, yine insanların elinden geleni yapması gerektiği de unutulmamalıdır. Belki sadece bir bireyin iklim değişikliğine direnç göstermesi etkisiz gibi gözükebilir. Ancak dünya nüfusunun 7,5 milyar olduğu unutulmamalıdır. Kirleten insanoğlu, kurtaracak olan da insanoğludur. Dünyanın tüm çevresi ve atmosferi, yani dünya ekolojisi arınma ihtiyacı duymaktadır.

"Resilience" kavramı afet yönetimi yazınında görüş birliği sağlanabilmiş bir terim değildir. Bazı kaynaklarda esneklik anlamında kullanılırken, son zamanlarda birçok kaynakta ise dirençlilik kavramı ön plana çıkmaya başlamıştır (Varol ve Kırıkkaya, 2017). UNISDR Terminoloji Kitapçığında, dirençlilik-resilience, "tehlikelere maruz kalan bir sistemin, topluluğun veya toplumun, temel ana yapı ve fonksiyonlarının korunması ve düzeltilmesi de dahil olmak üzere, söz konusu tehlikenin etkilerine zamanında ve etkili bir şekilde direnme, azaltma, bunlara uyum sağlama ve bunlardan kurtulma yeteneği" olarak tarif edilmiştir (2009: 
24). Dirençlilik terimi, iklim değişikliğine uyum ve afet riskinin azaltılması konusundaki tartışma, politikalar ve programlar bağlamında giderek daha fazla kullanılmaktadır. Bu iki alan ile yoksulluk ve gelişme alanları arasındaki kesişimi 'iklim değişikliğine dirençli gelişme' olarak tanımlamak önem kazanmıştır. 'Iklim değişikliğine dirençli gelişme' tanımlaması, hızlı bir şekilde iklim değişikliğinin etkileri konusunun kalkınma ile birlikte ele alınmasını hızlandırmıştır (Bahadur, vd., 2010:2).

İnsan vücudu, normal metabolizma çalışmasına bağlı oluşan toksinlerden arınmaya programlanmıştır. Ancak günümüz hızlı şehir yaşamı ek toksinlerin insan vücuduna alınmasına sebep olmaktadır. Vücut bu ek toksinlerle mücadelede zorlanmaktadır. Bu durum yorgunluk, bitkinlik, güçsüzlük, uykusuzluk, kas ve eklem gerginlikleri, stres gibi birbirini tetikleyen sağlık problemleri ortaya çıkmaktadır (Erdil, 2016: p.2). Detoksifikasyon (Arındırma), insan vücudunun istemediği maddelerin veya toksinlerin doğal yollarla etkisiz hale getirilmesi, dönüştürülmesi veya yok edilmesi olarak tanımlanmaktadır. (Lipman 2019, p.2). Yani diğer bir ifade ile "detoks (arınma)", yanlış ve kötü beslenme, kötü yaşam tarzı ve kirlenmiş hava, su gibi çevresel faktörler sebebi ile bu kirlilikten etkilenen insan vücudunun, belirli bir süre boyunca toksinlerden arındırılması ve temizlenmesi işlemi olarak tanımlanmaktadır. İnsan vücudu her gün detoks işlemini kendi kendine yapacak şekilde çalışabilmektedir.

Dünya biyosferini oluşturan canlı organizmaların tümünün kimyasal bileşimini, yüzey pH'ını ve iklimini düzenlemek için tek bir varlık gibi hareket edebileceği hipotezi ortaya atılmıştır. Biyosferin, Dünya'yı özdengede (homeostazide) tutabilen aktif uyumlu bir kontrol sistemi olduğu fikri "Gaia" hipotezi olarak adlandırılmaktadır (Lovelock ve Lynn 1974: 3). Gaia teorisi, Dünya sisteminin bir amplifikatör olarak hareket edebileceğini ve hem Isınmak hem de soğumak için yapılan küçük değişikliklerin yoğunlaşabileceğini ve bu nedenle düzensiz sıcaklık değişimlerinin ortaya çıkabileceğini vurgulamaktadır (Lovelock 2009: s.1). Bu hipoteze göre, Yerküre bir süper-organizmadır. Tüm bileşenleri birlikte hareket etmektedir. Yerkürenin canlı bir organizma gibi davranabildiği düşünülmektedir. Bu şartlarda Yerkürenin kirlenme sonucu yok olabileceği, krizler yaşayabileceği durumların yaşanması mümkündür. Maalesef, Yerküre insanlar tarafından hızla kirletilmekte ve biriken bu kirlilikten ve toksinlerden - ki karbon ve eşdeğeri sera gazları bu bağlamda değerlendirilmelidirarındırılması intiyacı net olarak görülmektedir. Yerküre insan vücudu gibi detoksa (arınmaya) intiyaç duymaktadır. İnsan vücudu gibi yorulabilen Yerküre'nin yorgunluğu, tahriş olma durumu, alerjisi ve enfeksiyon kapmış hallerini nasıl açıklayabiliriz? Dünya'da ki insan nüfusu ve sürekli artışı, artan tüketim ve üretim faaliyetleri yeryüzünde daha fazla iz bırakmaktadır. Tüketilen gıdalar, giysiler, diğer tüketim malları, ısınma ve ulaşım kaynakları ve atıklar söz konusu izin bırakılma yollarıdır. Ayrıca üretim sürecinde kullanılan hammaddeler ve yan ürünler de bu duruma ve sürece katkı yapmaktadır. Yerküre'nin yaşadığı çevre sorunlarının başında, aşırı tüketim sonucu yıkıma uğraması ve bunlara bağlı küresel ısınma ve iklim değişikliği sonuçları gelmektedir. Dünya'da çok büyük oranda bir ortak görüş olduğu kabul edilirse, tedavi için de sorunu yaratanların çare bulması gerekmektedir. Bu çareler, hükümetler, sosyal topluluklar, aile ve birey düzeyinde yapılacak ortak çalışmalarla işe yarayacaktır. Yerküre'nin genel hastalıkları; aşırı nüfus artışına bağlı olarak ortaya çıkan hava kirliliği ve iklim değişikliği, ormansızlaşma, türlerin yok olması, toprak bozulması, atmosferin kimyasal yapısının değişmesi gibi durumlardır.

$\mathrm{Bu}$ çalışmada, Yerküre ikliminin değişmesine neden olan insan faaliyetlerinin nasıl kısıtlanabileceği, bireylere veya topluma bunun için önerilen kavram "iklim için detoks (arınma)"un ne anlama geldiği ve detoks (arınma) yolları anlatılmaktadır. Hükümetler, üniversiteler, enstitüler iklimin neden hızla değiştiğine, insanoğlunun buna nasıl ve ne miktarda insan faaliyetlerinin sebep olduğuna dair birçok araştırma yapmakta, makaleler hazırlamakta, raporlar sunmaktadırlar. Tüm bu araştırmacılar ve politikacıların hem fikir 
olduğu önemli bir konu da yapılan bu çalışmaların halkın anlayacağı düzeyde hazırlanması ve farkındalığın artıılarak iklim değişikliğine direnç için topyekün bir katılım sağlanması gerekliliğidir. Bu farkındalık düzeyini artırmak ve halkın dikkatini daha çok çekmek amacıyla "iklim için detoks (arınma)" kavramının iklim değişikliği yazınına girmesinin yararlı olacağı düşünülmektedir. Bu farkındalığın artırıması için öncelikli olarak iklim değişikliği, sera gazı, küresel ısınmanın kanıtları, karbon ayak izinin ne olduğu ve nasıl tespit edildiği, kollektif ve bireysel "iklim için detoksun" ya da diğer adıyla "karbon detoksunun (arınma)" yapılma yolları incelenmiştir.

\section{KÜRESEL ISINMA ve İKLIMM DEĞişiKLİĞi}

Birleşmiş Milletler İklim Değişikliği Çerçeve Sözleşmesi (BMiDÇS) "Küresel iklim değişikliğinin, yerkürenin uzun jeoloji tarihi boyunca yaşanan iklimin doğal değişkenliğine ek olarak insan etkinliklerinin neden olduğu bir değişiklik" olduğunu belirtmiştir. Yine bu sözleşmede iklim değişikliği "karşılaştırılabilir bir zaman döneminde gözlenen doğal iklim değişikliğine ek olarak, doğrudan ya da dolaylı olarak küresel atmosferin bileşimini bozan insan etkinlikleri sonucunda iklimde oluşan bir değişiklik" biçiminde tanımlanmaktadır (UNFCC Fact Sheet 2011: 2).

İklim sistemi için önemli bir doğal etmen olan sera etkisi sayesinde, yerkürenin sıcak yüzeyinden salınan uzun dalgalı yer ışınımının (radyasyonu) bir bölümü, uzaya kaçmadan önce atmosferin yukarı seviyelerinde bulunan çok sayıdaki ışınımsal olarak etkin sera gazları tarafından emilir ve sonra tekrar yeryüzüne doğru salınır. Atmosfer dışına gitmesi gerekirken yeryüzüne fazladan salınan radyasyon küresel ısınmaya neden olan en önemli sebeptir. Doğal sera gazlarının en önemlileri, başta en büyük katkıyı sağlayan, su buharı $\left(\mathrm{H}_{2} \mathrm{O}\right)$ olmak üzere, karbondioksit $\left(\mathrm{CO}_{2}\right)$, metan $\left(\mathrm{CH}_{4}\right)$, diazotmonoksit $\left(\mathrm{N}_{2} \mathrm{O}\right)$ ve troposfer ile stratosferde bulunan ozon $\left(\mathrm{O}_{3}\right)$ gazlarıdır (Türkeş, 2001). Eğer insan yapımı sera gazlarının atmosfere salımı ve fosil yakıtların tüketimi fazla olursa doğal sera gazı etkisine insan müdahalesi başlamakta ve atmosferde bulunan doğal veya insan yapımı sera gazı salımları artmaktadır. Bu durum küresel ısınmaya ve buna bağlı iklim değişikliğine sebep olmaktadır. İnsan yapımı başlıca sera gazları; karbondioksit $\left(\mathrm{CO}_{2}\right)$, metan $\left(\mathrm{CH}_{4}\right)$, azot oksitler $\left(\mathrm{N}_{2} \mathrm{O}\right)$, hidro-florokarbonlar (HFCs), perfloro-karbonlar (PFCs), sülfür hegza florür $\left(\mathrm{SF}_{6}\right)$ gazlarıdır. Fosil ve biyokütle yakıtların yakılması, insan kaynaklı sera gazı salımlarının (emisyon) en büyük kaynaklarıdır. Çimento üretimi karbondioksit, tarım ve katı atık düzenli depolama sahaları metan gazı salmaktadır. Gübre kullanımı ve naylon üretimi, diazot monoksit ve buzdolabı ile klimalar için kullanılan florin ise sera gazı salımlarını artırmaktadır. Tarım amaçlı kullanım için arazi açıması, koyu renkli yüzeyin miktarını artırmakta ve sonuç olarak gelen güneş radyasyonu yansımaktan çok emilmektedir. Ormanların tahrip edilmesi nedeniyle arazi açılması karbondioksiti tutan ve depolayan ağaç ve bitkilerin azalması anlamına gelmektedir. Çölleştirme, atmosfere geçen toz miktarında artışa neden olması dolayısıyla güneşten Yerküre yüzeyine gelen enerjiyi azaltarak küresel ısınmayı yavaşlatan bir etkiye sahip olabilmektedir. Şehirleşme, şehir ısı adalarının, yani şehirlerde çevrelerine göre daha sıcak alanların oluşmasına yol açmaktadır (MGM, 2017:6).

İklim değişikliğiyle ilgili en güncel bilimsel, teknik ve sosyo-ekonomik bilgileri, çok sayıda bilim insanının katılımıyla, düzenli aralıklarla değerlendirerek raporlar halinde yayımlayan Hükümetlerarası İklim Değişikliği Paneli (IPCC), 2007 yılında Dördüncü Değerlendirme Raporu'nu yayınlamıştır. Bu rapora göre, iklim sisteminin şüphe götürmeyecek şekilde ısındığı ve 20. yüzyılın ortalarından bu yana ortalama yüzey sıcaklıklarında gözlenen artışın büyük bölümünün (\% 90) kuvvetli olasılıkla insan kaynaklı sera gazı salımlarındaki artıştan kaynaklandığı belirtilmiştir (MGM, 2017:6). 
Dünya'da 2016 yılı, endüstri öncesi döneme göre $1.1^{\circ} \mathrm{C}$ 'lik anomali (sapma) ile en sıcak yıl olmuştur. 2015-2016 El Nino olayı nedeniyle 2016 yılının ilk aylarında sıcaklıklar en yüksek derecelere ulaşmış ve yılın ikinci yarısında da uzun dönem ortalamaların çok üzerinde gerçekleşmiştir (WMO Report, 2017:1). 1880 yılından günümüze kadar, Dünya sıcaklık ortalamaları içerisinde en sıcak yıl ortalamaları 1990 yıllarının başından günümüze kadar ki son 25-30 yılda gerçekleşmiştir. Özellikle son yıllarda sıcaklık rekorlarının kıııldığı ve yıllık sıcaklık ortalamalarının giderek arttığı gözlemlenmektedir. İklim istatistikleri, Dünyada en sıcak yılın 2016 yılı olduğunu göstermiştir (DW Climate Report, 2019: p.2). Dünyadaki sıcaklık artış eğilimine benzer durum Türkiye için de görülmektedir. Türkiye'de de son yıllarda sıcaklık ortalamalarında önemli miktarda artışlar olurken, 2016 yılı 1971'den bu yana gerçekleşen dördüncü en sıcak yıl olarak kayıtlara geçmiştir. 2016 yılı ortalama sıcaklığı $14.5^{\circ} \mathrm{C}$ ile $1981-2010$ otuz yıllık referans periyodunun ortalama değeri olan $13.5^{\circ} \mathrm{C}$ 'nin $1.0^{\circ} \mathrm{C}$ üzerinde gerçekleşmiştir. İklim verilerine göre 2010 yılı Türkiye'de yaşanan en sıcak yıl olarak kayıtlara girmiştir (Coşkun vd., 2017: 2).

Küresel iklimdeki ısınma kesindir ve 1950'li yıllardan beri iklimde gözlenen değişikliklerin çoğu on yıllardan, bin yıllık bir zaman dönemine kadar daha önce hiç görülmemiş düzeydedir. Bu dönemde, atmosfer ve okyanuslar ısınmış, kar ve buz miktarları azalmış, ortalama deniz seviyesi yükselmiş ve sera gazlarının atmosferdeki birikimleri artmıştır. Karbondioksit $\left(\mathrm{CO}_{2}\right)$, metan $\left(\mathrm{CH}_{4}\right)$ ve diazotmonoksit $\left(\mathrm{N}_{2} \mathrm{O}\right)$ gazlarının atmosferik birikimleri (konsantrasyonları), en az son 800.000 yıllık dönemde hiç olmadığı kadar yüksek bir düzeye ulaşmıştır. $\mathrm{CO}_{2}$ birikimleri, temel olarak fosil yakıt yanması ve ikincil olarak net arazi kullanımı değişikliğinden kaynaklanan salımlar nedeniyle, sanayi öncesi döneme göre \%40 oranında artmıştır. Okyanuslar atmosfere salınan insan kaynaklı karbonun yaklaşık \%30'unu emerek asitlenmiştir (Türkeş vd., 2013: s.2).

\section{IKLIM DEĞIŞiKLIĞi PROJEKSIYONLARI}

IPCC'nin yaptığı değerlendirmelere göre, 2016-2035 periyodunda, eğer volkanik bir patlama veya güneş radyasyonunda uzun vadeli önemli değişiklikler olmazsa, referans olarak alınan 1986-2005 dönemine göre, küresel ortalama yüzey sıcaklık (GMST) anomalisinin $0,3^{\circ} \mathrm{C}$ $0,7^{\circ} \mathrm{C}$ değerleri arasında artması muhtemel olacaktır (orta güvenirlikte). RCP senaryolarına dayanan uzun vadeli projeksiyonlarına göre, 21. yüzyıl boyunca sıcaklıklar artmaya devam edecektir. Yine IPCC'ye göre, 21 yüzyıl boyunca yağış rejiminin ısınmaya tepkisinin düzenli olmadığı görülmektedir. Genellikle, nemli alanlar ile kurak alanlar ve nemli mevsimler ile kurak mevsimler arasındaki farkların artması beklenmektedir. Yakın gelecekteki değişikliklerin büyük oranda iklim sisteminin kendi iç değişkenliğinden etkilenmesi beklenmektedir. RCP8.5 senaryosuna göre yüksek enlemler ve ekvatoral pasifik okyanus, muhtemelen yıllık yağışlarda bu yüzyıl sonuna kadar bir artışa sahip olacaklardır. Birçok orta enlem alanlarında ve yarı tropikal kurak alanlarda yıllık ortalama yağışlar muhtemelen azalırken, yine birçok orta enlem yağışlı alanlarında yıllık ortalama yağış muhtemelen artacaktır. (Akçakaya vd., 2015: 55-57).

Türkiye için Meteoroloji Genel Müdürlüğü (MGM) tarafından yapılan iklim projeksiyonları ise 2016-2099 döneminde yıllık ortalama sıcaklıklarda RCP4.5 senaryosuna göre $1,5-2,5^{\circ} \mathrm{C}$ aralığında RCP8.5 senaryosuna göre ise $2,5-3,6^{\circ} \mathrm{C}$ aralığında artışlar öngörmektedir. MGM iklim projeksiyonlarında da Türkiye geneli yıllık ortalama toplam yağış miktarlarında yüzyılın ikinci yarısında azalma eğiliminin yanında, yine IPCC öngörülerinde olduğu gibi, yağışın yıl içerisinde dağılımındaki ve şiddetindeki düzensizlik eğilimlerinin artması beklentisi dikkat çekmektedir (Akçakaya vd., 2015: 67-70).

IPCC raporlarına göre, 1901'den itibaren sıcaklıkların farklı büyüklüklerde de olsa dünyanın hemen hemen her tarafında arttığı vurgulanmaktadır. Türkiye'nin olduğu bölgeye (Doğu 
Akdeniz, Türkiye, Karadeniz ve Hazar) dikkat ettiğimizde sıcaklıklardaki artışın Avrupa, Asya ve Afrika'daki geniş alanlara göre daha az kaldığı söylenebilir. Aynı dönem için Akdeniz Havzası'nda yağışların azalması söz konusu olacaktır. Bu azalmalar 1950 yılından itibaren daha da güçlenmektedir. Akdeniz Havzası'nın gelecekte iklim değişikliği ile ilgili olarak en kırılgan bölgelerden birisi olacağı vurgulanmaktadır (Türkeş vd., 2013:20).

\section{KARBON DETOKSU IÇiN KARBON AYAK IZI HESAPLAMA}

Geçmişe yönelik iklim değerlendirmeleri ve bu iklim değerlendirmelerinden yararlanılarak hazırlanan iklim projeksiyonlarında yüzyılın sonuna kadar ortalama sıcaklıklarda artışlar ve yağış miktarlarında azalma ile yağış rejiminde düzensizlikler beklenmektedir. Bu ise iklim değişikliğinden en çok etkilenmesi beklenen Doğu Akdeniz Havzası ve Türkiye'nin acil önlemleri hayata geçirmesi gerektiğini göstermektedir. Bu önlemler sadece hükümetler tarafından değil, doğrudan bireyler tarafından da alınabilecek önlemleri kapsamaktadır. İster hükümetler düzeyinde ister sivil toplum, aile ve birey düzeyinde olsun her olumlu çabanın olumlu bir geri dönüşü olacaktır. Bunun içinde uluslararası bilim camiası tarafından neler yapılabileceğine dair birçok önlem şekli tanıtılmaktadır. En kapsamlı ve anlaşıır yöntemlerden biri ise "karbon ayak izi" nin hesaplanmasıdır.

İnsanlığın intiyaçları sürekli büyürken, insanlık tüketim sınırlarını aşmakta ve gelecek nesilleri harcama pahasına bugünü yaşamaktadır. Bu alışkanlıklar yüzünden Dünyanın ekosisteminin üretebileceğinden daha fazlası tüketilmektedir. Ekosistemin ürettiğinden daha fazla tüketmeye, yani ekolojik açık vermeye $90^{\prime}$ 'ı yıllarda başlanmıştır ve bu açık gittikçe büyümektedir. İnsanlığın intiyaçlarını giderirken, gelecek nesillerin ihtiyaçlarını yok etmeden sürdürülebilir kalkınma ilkesine bağlı kalarak, bir ülkenin ekonomik ve sosyal gelişimi yönlendirilmelidir (Ruževičius, 2010: 711). Küresel iklim değişikliğine direnç için bireysel önlemler hala tartışılıp geliştirilmektedir. İnsanların hepsinin bilgilenmek, farkındalığını geliştirmek, ağaç dikmek ve korumak, enerjiden tasarruf etmek, elektrik tasarrufu yapmak, alışverişi bulunduğumuz bölgeden yapmak, daha az ve kısa mesafelere seyahat etmek, yenilenebilir enerji kullanmak, az tüketmek ve yeniden kullanmak, geri dönüştürmek ve bu farkındalıkları politika yapıcılara aktarmak gibi zorunlulukları vardır (IPA Climate Change Report, 2016: 14).

Ekolojik ayakizi (EF- Ecological Footprint) anlayışı 1990 yılında British Columbia Üniversitesi'nden Mathis Wackernagel ve William Rees tarafından ortaya atılmıştır (2004). Yıllık Ekolojik ayakizi (EF), bu göstergenin değerlendirme raporunu sunan uluslararası bir organizasyon olan "Global Footprint Network" tarafından hesaplanmaktadır (aktaran Ruževičius, 2010: 712). Ekolojik ayakizi, mevcut teknoloji ve kaynak yönetimiyle bir bireyin, topluluğun ya da faaliyetin tükettiği kaynakları üretmek ve yarattığı atığı bertaraf etmek için gereken biyolojik olarak verimli toprak ve su alanıdır (WWF, 2019). Ekolojik ayak izi bileşenleri; karbon ayak izi, orman ayak izi, tarım ayak izi, yapılaşma ayak izi, otlak ayak izi ve balıkçılık ayak izi olarak tanımlanmıştır. Türkiye'de ise en büyük paya \%46 ile Karbon Ayak izi sahiptir (WWF, 2012: 9).

"Karbon Ayakizi Hesaplama" çalışmaları bireysel ve kurumsal boyutta, hem de ürün ve servis boyutunda hesaplanabilmektedir. Bir tanıma göre; karbon ayak izi, birim karbondioksit cinsinden ölçülen, kurum veya bireylerin ulaşım, ısınma, elektrik tüketimi vb. faaliyetlerinden kaynaklanan toplam sera gazı salım miktarıdır. Karbon ayak izi, doğrudan/birincil ya da dolaylı/ikincil ayak izi olarak sınıflandırılmaktadır. Birincil ayak izi evsel enerji tüketimi ve ulaşım (sözgelimi araba ve uçak) dahil olmak üzere fosil yakıtlarının yanmasından ortaya çıkan doğrudan $\mathrm{CO}_{2}$ emisyonlarının ölçüsüdür. İkincil ayak izi ise kullandığımız ürünlerin tüm yaşam döngüsünden bu ürünlerin imalatı ve en sonunda bozulmalarıyla ilgili olan dolaylı $\mathrm{CO}_{2}$ 
emisyonlarının ölçüsüdür (karbonayakizi, 2019). Karbon ayakizi hesaplamasında uluslararası alanda çeşitli metodoloji ve standartlar vardır. Kyoto Protokolü kapsamında değerlendirilen altı ana sera gazının $\left(\mathrm{CO}_{2}, \mathrm{CH}_{4}, \mathrm{~N}_{2} \mathrm{O}, \mathrm{PFc}, \mathrm{HFC}, \mathrm{SF}_{6}\right)$ standartlarının başında Hükümetler Arası İklim Değişikliği Paneli (IPCC)'nin yayınlamış olduğu metodolojilerin yanında, GHG Protokolü, ISO 14064, CDP, PAS 2050 gibi standartlardan söz edilebilir. Sera Gazı Protokolü (GHG), şirketler için dünyanın en yaygın kullanılan sera gazı muhasebe standartlarını sunmaktadır (Makinatek, 2019). GHG Protokolü standartları ve rehberliği, şirketlerin sera gazı emisyonlarını faaliyetlerinden ve değer zincirlerinden ölçmelerini, yönetmelerini ve rapor etmelerini sağlar. Ayrıca, Sera Gazı Protokolü, ülkelerin ve şehirlerin iklim hedeflerine doğru ilerlemelerini takip etmelerine yardımcı olan standartlar ve araçlar sağlar. ISO 14064 endüstriyel şirketlere ve devlete Sera Gazı (GHG) salınımlarını azaltmaya yönelik programlar geliştirmek için bir dizi araç sunar. CDP ve PAS 2050 gibi benzer sera gazı hesaplama standartları da karbon ticareti rekabetinde şehirlerin ve firmaların katılımını kolaylaştırmak için geliştirilmiş standartlardır (BSI, 2019).

Bu çalışmada aileler ve bireylerin, evde, ofiste ve diğer tüm yaşamlarında, ekolojik ayakizi'ni doğrudan azaltmalarını sağlayacak önlemler ele alınmıştır. Bu önlemleri uygulayarak iklim için "karbon detoksu (arınma)" yapmanın yolları tartışılıştır. Tüm Dünyada ve Türkiye'de ekolojik ayakizi'nin ne ifade ettiğini anlamaya yarayan bazı sayaçlar bulunmaktadır. Bu sayaçlar, birey, aile ve toplum olarak yerküreye getirilen yükün anlaşılması ve ona göre önlemler alınmasını sağlayan uyarı ve yönlendirme mekanizmalarıdır. Ayrıca ulusal veya uluslararası istatistikler de yararlanılabilecek diğer yol gösterici mekanizmalardır.

Karbon ayakizi hesaplama mekanizmaları konunun anlaşılmasına yardımcı olabilir. Çekirdek bir ailenin karbon ayak izi hesaplamasında birinci madde genellikle "beslenme" maddesidir. Sığır eti ve süt ürünleri endüstrisinin yaydığı gazlar, günümüzde sera gazı salımlarının \%15'inden sorumludur. Sera gazı salım oranlarının 2050 yılına kadar et tüketimi için yüzde 75 , süt ürünleri tüketimi için ise yüzde 65'e ulaşacağı tahmin edilmektedir. Tahıl ürünleri için bu oran yüzde 40 olarak tespit edilmiştir (Çelik, 2015, p.19). Günümüzde dünyada birçok yerde kuraklık yaşanmasına rağmen buzul harici toprakların toplamının yüzde 30 'u çiftlik hayvanları için otlak olarak, ekilebilir toprakların yüzde 33'ü ise çiftlik hayvanları için yem üretim sahası olarak kullanılmaktadır. Hâlbuki bu topraklar milyonlarca insan için bitkisel üretim sahaları olarak kullanılabilir. Çiftlik hayvanlarının insan kaynaklı sera gazı toplam salımı içindeki payı \%18 civarındadır. Bu oran ulaşım sektörünün etkisinden büyüktür. Ayrıca küresel tarım sektörünün tüm sera gazları içerisindeki payı \%80'lik bir dilimi kapsamaktadır. Örneğin Dünya Sağlık Örgütü'nün tavsiye ettiği sınırdan 3,5 katı daha fazla et tüketen Britanya vatandaşlarının, bir yıl içerisinde sadece bir gün et yemeseler yılda 13 megatonluk $\mathrm{CO}_{2}$ salımı tasarrufu yapmış olmaları mümkündür. Bu ise 5 milyon arabanın trafikten men edilmesine eşit bir önlemdir. Sayıları hızla artan günümüzdeki etlik çiftlik hayvanı sayısı 60 milyar ve sığır sayısı 1 milyardan fazladır (Lewoxx, 2012, p.15-17). Türkiye'de canlı hayvan varlığının toplam sera gazı salımları içindeki payı \%5.87'dir. Dünyada canlı hayvan varlığının sera gazı emisyonlarına etkisine bakıldığında en yüksek oran \%35.32 ile Yeni Zelanda'da ve \%18.22 ile İrlanda'da görülmektedir. Amerika Birleşik Devletleri'nde bu oran \%4.59, AB'de ise \%4.36 olarak tespit edilmiştir (Yeo, 2019, p.31-32). Henrich Böll Vakfı'nın 2014 Ocak ayında yayınladığı et atlasına göre, bir kg et üretimi için 15 bin 500 litre su harcanmaktadır. $\mathrm{Bu}$ raporda et üretimi için harcanan su miktarının tarımsal üretime göre çok daha fazla olduğu vurgulanmıştır (Çelik, 2015, p.19). Karbon ayakizi hesaplama sayaçları; İkinci olarak, tüketilen yiyeceğin ne kadarı işlenmemiş, paketlenmemiş veya yerel olarak yetiştirilmektedir, bununla ilgilenmektedir. Kaç kilometre uzaktan getirilmekte olduğunu sorgulamaktadır. Buradaki amaç tüketilen gıdaların mümkün olduğunca tüketicinin yaşadığı yörede üretilmesi, işlenmesi (mümkünse işlenmemesi), paketlenmesi (mümkünse paketlenmemesi) ve dağıtılmasını teşvik etmektir. Diğer önemli bir soru "Hane" (Housing) çeşidi, insanların hangi konut tipinde ikamet ettiği sorusudur. Bu evlerin su kaynaklarına yakın olup olmadığı, çok 
katlı daire mi, dubleks-sıra tipi ev mi veya lüks bir apartman katı mı olduğunu sorgular. Bu konutların hangi malzemeyle inşa edildiği sorusu da çok önemlidir (saman/bambu, ahşap, tuğla/beton, kerpiç, çelik/diğer vb.). Mimari ve inşaat sektörü enerjiyi daha az tüketen binalar tasarlamak zorundadır. Bunun için ise daha uzun süre dayanan daha az işlenmiş malzeme kullanımı teşvik edilmelidir. Ayrıca, evlerde binalarda kişi başına düşen alanları azaltmak, sera gazı emisyonuna olumsuz katkı yapan inşaat üretim malzemelerinin daha az kullanımı anlamına geleceğinden $\mathrm{CO}_{2}$ salımı azalacak ve enerjide kaynak verimliliği artacak, özellikle sera gazı salımlarından \%84 oranında sorumlu olan enerji tüketimi azalacaktır. Hatta kendi yenilenebilir enerjisini üreten binalar teşvik edilmelidir. Başlıca yenilenebilir enerji kaynakları güneş, rüzgar, jeotermal, hidrolik, biyo-kütle, dalga ve hidro-elektrik santralleridir. 2014 yılında Dünya'da enerji tüketiminde yenilenebilir enerjinin payı yüzde 19,2 olarak gerçekleşmiştir. 2015 ve 2016 yılları itibari ile \%20'yi aşmıştır ve enerjinin yaklaşık beşte biri (1/5) yenilenebilir kaynaklardan karşılanmaktadır. Uluslararası Enerji Ajansı'na (IEA) üye olan Türkiye, elektrik üretiminde yenilenebilir enerji kaynaklarını en çok kullanan on üçüncü ülkedir. Türkiye'nin 2023 hedeflerinde elektrik üretiminde yenilenebilir kaynaklardan (hidroelektrik dahil) elde edilebilmesi oranının yüzde 30 seviyelerine çıkarılabileceği tahmin edilmektedir (Karagöl ve Kavaz, 2017, s.8-9). Karbon ayakizi hesaplamada konutlarda atık değerlendirme diğer önemli bir başlık olarak ele alınmaktadır. Atık yönetimi iyi yapılırsa, iklim değişikliğine direnç için hem olumsuzluklar bertaraf edilmiş hem de atıkların geri dönüşümü ile doğal kaynakların daha az kullanılması sağlanmış olur. Vahşi atık depolama sahaları metan üretip havaya bırakırken, bu metandan enerji üretimi ile iklim değişikliğine direnç artırılmış olmaktadır. Atık yönetimi hanelerden başlar. Organik atıklar ve diğer atıkları ayrıştırmak karbon ayakizi'ni oldukça azaltmaktadır. Bu sayede daha az su ve enerji kullanııı, daha az ağaç yok edilir ve tabi ki daha az sera gazı salımı yapılmış olur. Atıkları yönetmenin en doğrudan yararı, daha az çevre kirliliğidir. Atık hiyerarşisi; önleme, azaltma, yeniden kullanım, geri dönüşüm, enerji geri kazanımı ve bertaraf şeklinde sıralanabilir. Örneğin, hurda kâğıdın geri dönüşümü sayesinde hava kirliliği \%74-94, su kirliliği \%35, su kullanımı \%45 azalmaktadır. Sıfırdan kağıt üretme işlemlerine kıyasla, geri dönüşüm, \%60 enerji tasarrufu, \%80 su tasarrufu ve \%95 hava kirliliği azaltımı sağlayabilmektedir. 1 ton kağıt geri dönüşümü sayesinde $0,8 \mathrm{~m}$ uzunluğunda 17 tane ağacı, $26,5 \mathrm{~m}^{3}$ suyu, 2 varil (318 It) petrolü, $4100 \mathrm{kWh}$ enerjiyi (ortalama bir eve 6 ay yetecek kadar enerji) korumak mümkündür. Plastik geri dönüşümü ile $\% 80-90$ enerji tasarrufu sağlanabilmektedir. Türkiye'de evsel atıklar, toplam oluşan atıkların \%42,8"ini oluşturmaktadır. İkinci en yüksek atık miktarı enerji sektöründedir (TMMOB, 2018, s.20). Konutlar ve iş yerlerimizdeki karbon ayakizi'nin fazla olması bireylere oldukça fazla yükümlülük yüklerken aynı zamanda alınabilecek birçok önlem fırsatı da sunmaktadır. Karbon ayakizi hesaplamada taşıma ve ulaşım başlığı, tüm insanların içinde olduğu ve en kolay önlem alınabilecek durumlardan biridir. Taşıma ve ulaşımda, en sık kullanılan araçların ortalama yakıt ekonomisi önemlidir. Bu sayede daha az veya daha çok karbon salımı yapılabilmektedir. Taşımada toplu taşıma araçlarının kullanılması daha az karbon salımı için önemli bir alışkanlık ve önlemdir. Avrupa'da en çok karbon salımı yapan kara taşıtları olan dizel araçların yasaklanması eğilimi hızla artmaktadır. Son bazı gelişmeler göstermektedir ki teşvik amaçlı olarak toplu taşımanın ücretsiz hale getirilmesi çalışmaları hız kazanmıştır. Taşımada en fazla karbon salımını uçaklar yapmaktadır. Hava yolculuğu ve taşımacılığı yukarı atmosfere doğrudan karbon türevi gazlar bıraktığından dolayı iklim için en tehlikeli taşıma ve yolculuk yöntemi olarak karşımıza çıkmaktadır. Karbon ayak izi hesaplarken en büyük etken yıl içerisinde yapılan yurt içi ve yurt dışı uçuşlar olmaktadır. Türkiye'de ulaştırma sektörü $\mathrm{CO}_{2}$ salım miktarının enerji sektörü içindeki payı \%22,2, ulusal toplam emisyondaki payı ise \%15’tir (aktaran Bıyık ve Civelekoğlu 2018: 157).

Ortalama bir insan ve ailesi için yapılan karbon ayak izi ölçümü sonucunda ürkütücü sonuçlar ortaya çıkmaktadır. Yani bir apartman dairesinde oturan, evinde her türlü elektronik eşya 
bulunan, işine dizel aracıyla giden, tablet, cep telefonu gibi elektronik eşyalarını her yıl değiştiren ve yılda birkaç kez yurt içi ve yurt dışı uçuş yapan bir birey tek bir Yerküre varlığı ile yetinememektedir. Bu durum sürdürülemeyeceği için Dünyamızı büyük bir karmaşa beklemektedir. İnsanın doğal kaynakları tüketme hızı, doğanın kendini yenileme hızının \%50'sini geçmiştir ve ekolojik ayakizi hesaplamaları göstermektedir ki bir Kuzey Amerikalının 5, bir Avrupalının 3, Türkiye'de yaşayan birisinin ise 2 gezegene ihtiyacı vardır (WWF, 2019). Eğer karbon ayakizi hesaplaması optimum değerlerle yapılırsa; yani besinde vegan (sadece sebze meyve tüketen) ve hep yöresinden beslenen, en küçük ve bağımsız evde oturan, ev yapımında saman veya bambu kullanan, yalnız yaşayan, elektrik kullanan ancak en verimli şekilde yararlanan, yeşil enerji kullanan, oldukça az atık üreten, taşımada hiç araba ve mobilet kullanmayan, toplu taşıma kullanan ve uçağa binmeyen birisi ise 0.3 oranında dünyaya yük olmaktadır. Yani yerkürenin onun için sunduklarının yüzde otuzundan yararlanmaktadır. Karbon ayakizi hesaplaması maksimum yapıldığında; yani çok sık et tüketen, besinlerini kendi yöresinden almayan, aşırı lüks, çelik veya betonarme bir binada oturan, ailesinde ondan fazla kişinin yaşadığı, oturduğu ev çok büyük olan, yenilenebilir yeşil enerjiden hiç yararlanmayan, çok fazla atık üreten, sürekli özel ve verimsiz bir araba kullanan, hiç toplu taşıma kullanmayan ve sürekli uçak yolculuğu yapan birisi ise sanki 17.4 tane yerküre varmış gibi yaşamaktadır. Dünya için $\mathrm{CO}_{2}$ salımımız 64 ton/yıldır. Bu şekilde yaşayan bir birey 29.7 gha (Global Hectares) alana intiyaç duymaktadır. Halbuki dünya kişi başına 1.7 gha alan sunabilmektedir (Globalfootprintnetwork, 2019, p.2).

2016 yılı verilerine göre; Türkiye için toplam sera gazı emisyon miktarı 1990 yılına göre \%135,4 oranında artmıştır. Türkiye'de kişi başına düşen sera gazı emisyon miktarı da 2015 yılında 6.04 ton $\mathrm{CO}_{2}$ eşdeğerinden 2016 yılında 6.30 tona yükselmiştir (Gündoğan, 2018). Dünyada 2011 Yılı, ülkelerin Sera Gazı Emisyonlarının Karşılaştırmasına göre; emisyon payları Çin \% 19, ABD \%18, Hindistan \% 4.9, Rusya \%5, Japonya \%4 ve Türkiye \%1 oranında gerçekleşmiştir (ÇŞB, 2019). 2014 yılı için ise ülkelerin toplam sera gazı içerisindeki oransal olarak sorumlulukları Çin \% 30, Amerika \%15, AB \%9, Hindistan \%7, Rusya \%5, Japonya \%4 ve tüm diğerleri \%30 (Türkiye \%1) oranında olmuştur (EPA, 2019, şekil 3). 2011-2014 yılları arasındaki ülkelerin sera gazı emisyonlarının değişimine bakarsak özellikle Çin çok büyük bir artış göstermiş ve Hindistan da buna katkı yapmıştır. Bu ise sera gazı salımlarında en büyük nüfusa sahip bu iki ülkenin sera gazı salımlarına olumsuz katkı senaryosunun gerçekleşmekte olduğunu göstermektedir. Amerika Birleşik Devletlerinin sera gazı salımı oranını \%18' den \%15'e düşmüştür. İstatistiklerde 2011 ve 2014 ABD sera gazı salım oranlarının hemen hemen aynı olması, oransal bu değişimin sebebi, Çin ve Hindistan gibi ülkelerin toplam üzerine yaptıkları artış yüzünden gibi görünmektedir.

\section{SONUÇ}

İklimi ve iklim değişikliğini anlamak, sebep olunan bu yıkıma müdahale edebilmek için bilimsel çalışmaları ciddiye almak ve ortak önlemlere katılım sağlamak gerekmektedir. Dünya bilim çevreleri, Dünya ikliminin dününü, bugününü anlamaya çalıştıkları gibi geleceğini de anlamak için çalışmalar yapmaktadırlar. Birleşmiş Milletler İklim Değişikliği Çerçeve Sözleşmesi (BMiDÇS) ve IPCC (Hükümetlerarası İklim Değişikliği Paneli) gibi uluslararası çalışmalar ile hem hükümetler hem de bireyler düzeyinde yapılabilecekler uzun yıllardır tartışılmaktadır. Maalesef iklim değişikliğine tarihi olarak olumsuz katkıları olan birçok gelişmiş ülke bu çağrıları dikkate almayarak, gelişmekte olan ülkelerden sorumluluklarının az olmasına rağmen küresel ısınmaya bağlı iklim değişikliğine direnç için büyük katkı yapmalarını beklemektedirler. Hâlbuki iklim konusu ve sorunları sınır tanımamaktadır. Kutuplarda yaşanan bir sorunun Türkiye'yi ya da Ekvator Kuşağı'ndaki herhangi bir ülkeyi etkilemeyeceğini kimse söyleyememektedir. Amazon Yağmur Ormanlarının yok olması sadece Güney Amerikalıların sorunu olmayacaktır. Sürekli asitleşerek yaşamın yok olduğu okyanuslar her ülkeyi etkilemektedir. İklim değişikliğinden en çok etkilenmesi beklenen 
bölgelerden birisi Türkiye'nin de içinde bulunduğu Doğu Akdeniz bölgesidir. Hızla yok olan dağ buzulları yüzünden hemen hemen her ülkenin tatlı su kaynakları azaltmakta veya kurumaktadır. Eriyen kutup buzulları deniz seviyelerini yükseltmekte ve biyolojik çeşitliliğe ve kıyı kentlerinin varlığına tehdit oluşturmaktadır. Isınan okyanuslar daha fazla ve daha şiddetli tropik fırtınaya neden olmakta, mercan resiflerini ve buna bağlı olarak da birçok balık türünün yok olmasına neden olmaktadır. Domino etkisi yaratan tüm bu olumsuz gelişmeler besin zincirini bozarak, tarımsal faaliyetleri olumsuz etkileyerek gıda güvenliği sorununu büyütmektedir. Bunun sonucunda büyük kitlesel göçler ve bunların tetiklediği güvenlik sorunları ya da savaşlar çıkmasına neden olmaktadır. Şehirlerde güvenli, sağlıklı bir ortamda yaşamın devam edebilmesi için organik bir canlı gibi davranan Yerküre'nin hastalandığı kabul edilmelidir. Bu hastalığa sebep olan insanoğlu çözümü bulacak olan taraftır. Dünyada yaşayan yaklaşık yedi buçuk milyar insanın iklim değişikliğine direnç için görev ve sorumlulukları vardır. Bu sorumluluklar, çok küçük davranış değişiklikleri ile dahi olumlu gelişmeleri sağlayabilmektedir.

Küresel iklim değişikliğine direnç için bireylere önerilen ve İngilizce 3R (R küp)'nin anlamının bilinmesi gerekmektedir. 3R; Reduce (azalt), Reuse (yeniden kullan) ve Recycle (geri dönüştür) anlamına gelmektedir. Tüketimi ve israfı azaltıp yeniden kullanımı ön plana çıkaran unsurlardır. Politika yapıcılar iklim değişimi problemine karşı tüm insanların duyarlı olduğunu bilmek zorundadırlar (IPA, 2016: 14). Belki de en üzücü olan durum, insanoğlu bu mücadelede başarısız olursa ve insanların soyu tükenirse, Dünya sistemi (Gaia), büyük bir yıkıma uğrayacaktır. Belki de Gaia kavramının en büyük anlamı, insanlığa O'nun bir parçası olduğunu ve Gaia ile olan sözleşmesinin sadece insan hakları ile ilgili olmadığını, aynı zamanda insan yükümlülüklerini de içerdiğini hatırlatan ve yaşayan bir Dünya metaforunda yatmaktadır. (Lovelock, 2008: s.3889). Dünyamızın yaşaması ve iyileşmesi mümkün görünmektedir. Bu makale insanların özellikle de bireyler düzeyinde yapabileceklerinin önemine vurgu yapmak için hazırlanmıştır. Yetmiş veya seksen yıllık insan ömründe insan bedeninin değerini bilip onu arındırmak, ruhen ve fiziksel dinlenmesini sağlamak için yapılanlar, yaşayan bir organizma olan Yerküre için de yapılmalıdır. Yapılabileceklerin ilki birey ve aile olarak karbon ayakizi'nin tespit edilip, hemen uygulamaya geçilmesidir. Bir birey için hesaplanan karbon ayakizi sonuçlarının, yaklaşık yedi milyar ile çarpıldığında ne kadar büyük bir önlem olduğu bilincine sahip olunmalıdır. Detoks kavramı, insanın hayatının her aşamasında kullandığı ve değişik sebeplerle arınma ihtiyacını ortaya koyduğu bir yaklaşımdır. Özellikle son zamanlarda ruhen ve bedenen yapılan detoks yaklaşımına yenileri eklenmiştir. Ruhsal, bedensel, zihinsel, duygusal, dijital, medya detoksu (arınımı) kavramları insan hayatına dahil olmuştur. Bunlara karbon detoksu (arınımını) kavramı da eklenmelidir. Aslında uluslararası literatürde yeni olmayan bir kavramdır. George Marshall tarafından yazılmış olan "carbon detox" u adlı eser de aynı yaklaşımı göstermiş bir eserdir (2007). Dünyada yaşayan her birey karbon salımına katkı yapan tüm alışkanlıklarını azaltarak ve zaman zamanda sonlandırarak arınmaya katkı yapabilir. Enerji tasarrufu yaparak, yeterli beslenerek ve fazlasını tüketmeyerek, ulaşımı temiz enerji kullanan yöntemlerle veya az enerji tüketen yöntemlerle yaparak, minimalist yaşayarak Yerküre'nin arınmasına fazlasıyla katkı yapılabilir. "Karbon detoksu" yaşamımızın bir parçası olmalıdır. Çünkü Gaia yaşayan bir organizmadır ve insanların en gerçek ve tek yuvasıdır. 


\section{KAYNAKLAR}

Akçakaya, A., vd., (2015), "Yeni Senaryolarla Türkiye Iklim Projeksiyonları ve İklim Değişikliği TR2015-CC" Meteoroloji Genel Müdürlüğü Yayını, 149 s., Ankara.

Bahadur, A.V., vd., (2010), "The resilience renaissance? Unpacking of resilience for tackling climate change and disasters", Strengthening Climate Resilience, Discussion Paper 1, Brighton, UK, 1-45.

Bıyık, Y., ve Civelekoğlu, G., (2018), "Ulaşım Sektöründen Kaynaklı Karbon Ayak İi Değişiminin Incelenmesi,", Bilge International Journal of Science and Technology Research, 157-166.

BSI, (2019) “Sera Gazı Emisyonlarının Doğrulaması (EU ETS"), "https://www.bsigroup.com/tr-TR/Sera-Gazi-Emisyonlari-Dogrulamasi/, p. 10, (17.01.2019).

Çelik, E., (2015), "Et tüketimi iklim değişikliğinin etkilerini arttırıyor”, https://gaiadergi.com/ettuketimi-iklim-degisikliginin-etkilerini-arttiriyorl, (28.01.2019).

Coşkun, M., vd., (2017) “2016 Yılı Iklim Değerlendirmesi” MGM Basımevi, Ankara.

ÇŞB Rapor, (2019), "Türkiye ve Diğer Ülkelerin Sera Gazı Emisyonlarının Karşılaştırılması” http://iklim.csb.gov.tr/turkiye-ve-diger-ulkelerin-sera-gazi-emisyonlarinin-karsilastirilmasi-i4410, (17.01.2019).

DW Climate Report, (2019), "Top stories/environment, climate change", https://www.dw.com/en/global-warming-2017-was-second-warmest-last-three-years-arerecord-hot/a-42217407, (17.01.2019).

EPA Report, (2019), "Global Emissions by Gas" https://www.epa.gov/ghgemissions/globalgreenhouse-gas-emissions-data\#Country, doi 10.3334/CDIAC/00001_V2017, (17.01.2019).

Erdil, D., (2016), "Sağlıklı ve uzun bir yaşam için arınma: Detoks mucizesi", https://www.uplifers.com/saglikli-ve-uzun-bir-yasam-icin-arinma-detoksmucizesi/\#ixzz5dK4wMgeJ", (22.01.2019).

Globalfootprint, (2019), "Sustainable Development", https://www.footprintnetwork.org/ourwork/sustainable-development/, (28.01.2019).

Gündoğan, A.C., (2018), “Türkiye'nin Toplam Sera Gazı Emisyonu ve Kişi Başına Düşen Emisyonlar 2016'da da Artış Kaydetti”, https://www.iklimhaber.org/turkiyenin-toplam-seragazi-emisyonu-ve-kisi-basina-dusen-emisyonlar-2016da-da-artis-kaydetti/, (17.01.2019).

IPA Climate Change Report, (2016), "íklime Dirençli Kentler”, Türkiye İklim Değişikliği 6. Bildirimi, Türkiye Cumhuriyeti Çevre ve Şehircilik Bakanlığı Yayınları, 2016, Ankara. S, 22, 161.

Lewoxx, (2015), "Et yemenin iklim değişikliğine katkısı", Çevre Sorunları, Toplumsal Sorunlar, Çeviren: F. Levent Şensever, http://www.altust.org/2012/02/insanin-evrimindeetoburlugun-anlami-et-yemenin-iklim-degisikligine-katkisi/, (28.01.2019).

Lipman, F., (2019), "What Do You Mean By Detox?” https://www.bewell.com/blog/what-doyou-mean-by-detoxl, (17.01.2019). 
Lovelock, J.E., ve Margulis, L., (1974), “Atmospheric homeostasis by and for the biosphere: the gaia hypothesis" Tellus, 26:1-2, 2-10, DOI: 10.3402/tellusa.v26i1-2.9731, s.3).

Lovelock, J..E, (2008), "A geophysiologist's thoughts on geoengineering", Phil. Trans. R. Soc. A (2008) 366, doi:10.1098/rsta.2008.0135, s.3883-3890.

Lovelock, J..E, (2011), "Climate change on a live Earth", Institut D'estudis Catalans, Barcelona DOI: 10.2436/20.7010.01.103 Issn: 1575-6343, s.17-20.

Karagöl, E.T. ve Kavaz, İ., (2017), "Dünyada ve Türkiye'de Yenilenebilir Enerji”, Analiz, Sayı: 197, SETA, S 8-9).

Karbon Ayakizi, (2019), "Karbon ayakizi nedir?", http://www.karbonayakizi.com/whatiscarboonfootprint.html, (17.01.2019).

Kazak, E., (2014), “iklim değişikliğinin gıda güvenliğine etkileri ve pratik bilgiler”, https://www.gaiadergi.com/iklim-degisikliginin-gida-guvenligine-etkileri-ve-pratik-Bilgiler/, (17.01.2019).

Makinatek, (2019), "ISO 14064 ve GHG Protokolü" http://makinatek.com.tr/uncategorized/iso-14064-ve-ghg-protokolu/, (17.01.2019).

Mann, M. E., (2002), "Little Ice Age", The Earth system: physical and chemical dimensions of global environmental change, Volume 1, pp 504-509, s.1-6.

Man, W., vd., (2014), "Effects of Large Volcanic Eruptions on Global Summer Climate and East Asian Monsoon Changes during the Last Millennium: Analysis of MPI-ESM Simulations", Journal Of Clımate, Volume 27, s.7394-7409.

Marshall, G., (2007), "Carbon Detox: Your step-by-step guide to getting real about climate change", Hachette UK, s.1-256.

MGM, (2017), “iklim” https://www.mgm.gov.tr/iklim/iklim.aspx?k=B (17.01.2019).

MGM Report, (2018), “2017 Yılı Iklim Değerlendirmesi”, Araştırma Dairesi Başkanlığı, Klimatoloji Şube Müdürlüğü, 2018, Ankara, MGM Yayınları, S. 1-4.

Ruzevicius, J. (2010). "Ecological Footprint as an Indicator of Sustainable Development", Economics and Management: 2010, s.15.

Şarlak, N., (2015), "Paleoklimatoloji ve Filyos Nehri Paleo Akımlarının Türetilmesi”, 4. Su Yapıları Sempozyumu, Antalya, s. 500-507.

TMMOB Rapor, (2018), "Dünya çevre günü Türkiye Raporu", Çevre Mühendisleri Odası, Ankara, 1-31.

Türkeş, M., (2001). "Hava, Iklim, Şiddetli Hava Olayları ve Küresel Isınma”. Meteoroloji Genel Müdürlüğü, 2000 Yılı Seminerleri, Teknik Sunumlar, Seminerler Dizisi: 1: 187-205.

Türkeş, M., vd., (2013), “íklim Değişikliğinde Son Gelişmeler: IPCC 2013 Raporu”, İstanbul Politikalar Merkezi, Sabancı Üniversitesi, İstanbul. 
UNFCCC Fact Sheet, (Şubat 2011), "Fact sheet: Climate change science - the status of climate change science today", (23.01.2019).

UNISDR Terminology, (2009), “Disaster, Risk, Reduction” Geneva: UNISDR, 1-35.

Wackernagel, M., vd., (2004). "Using Ecological Footprint accounts: from analysis to applications", International Journal of Environment and Sustainable Development, 3 (4), 293315.

WMO Report, (2017), "2017 is set to be in top three hottest years, with record-breaking extreme weather", https://public.wmo.int/en/media/press-release/2017-set-be-top-threehottest-years-record-breaking-extreme-weather, (17.01.2019).

WWF Report, (2012), "WWF Türkiye'nin Ekolojik Ayak İi Raporu", İstanbul, 1- 89s, https://www.footprintnetwork.org/content/images/article_uploads/Turkey_Ecological_Footprin t_Report_Turkish.pdf, (17.01.2019).

WWF Report, (2019), "Sustainable Development", https://www.footprintnetwork.org/ourwork/sustainable-development/, (17.01.2019).

Varol, N., ve Buluş Kırıkkaya, E. (2017), "Afetler Karşısında Toplum Dirençliliği”, Dirençlilik Dergisi 1(1), 2017, (1-9) ISSN: 2602-4667.

Yeo, S., (2016), "Emissions, Animals", https://www.carbonbrief.org/seven-charts-showingcountries-carbon-footprints, (17.01.2019). 